\title{
Human Resource Management (HRM) Practices and Employee Job Satisfaction at a Public Corporation in Qatar
}

\author{
By: Dr. Thamer Mohammed Maharmeh \\ Ph.D. in Business Administration, Institute of Administrative Development, \\ State of Qatar \\ Email: gatarcountry@gmail.com
}

\begin{abstract}
:
Recognizing the importance of human resource management (HRM) practices, and their effects on employee behaviors and attitudes, many studies investigated the correlation between HRM practices and employee job satisfaction. The overall objective of this research is to investigate the impact of HRM practices (training and development and performance management) on employee satisfaction in case of a public corporation in Qatar. In order to meet the objectives of the research, and in order to answer its questions, a survey questionnaire was developed and distributed to a simple random sample of (92) employees, who work for a public corporation in Qatar. The total number of the returned surveys was (78) surveys. This means that the response rate was $84 \%$. Results of data analysis revealed that there is positive and strong correlation between HRM practices and employee job satisfaction. HRM practices explain $22 \%$ of employee job satisfaction, while other factors explain $78 \%$. Based on that, it was suggested to develop HRM practices in order to foster employee job satisfaction. It was also suggested to carry future researches to investigate other factors that may drive employee job satisfaction.
\end{abstract}

Keywords: HRM practices, Job satisfaction, Training and development, Performance management, Public corporation. 


\section{أثر ممارسات لموارد البشرية على الرضا الوظيفي لموظفي مؤسسة عامة قطرية

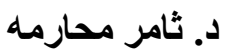
دكتور اه إدارة أعمال، معهد الإدارة العامة، دولة قطر

نظر الأهمية تحسين مستوى الرضا الوظيفي للموظفين، فقد جاء هذا البحث لدر اسة أحد العو امل التي قد تؤثر في الرضا الوظيفي وهو ممارسات الموارد البشرية. هدف البحث إلى الكثف عن تأثنير ممارسات الموارد البشرية، تحديدا ممارسات التدريب و التطوير وتقييم الأداء الوظيفي، على الرضا الوظيفي لموظفي مؤسسة عامة بدولة قطر. تم تصميم استبانة وتوزيعها على عينة عشو ائية بسيطة من موظفي المؤسسة العامة. بلغ عدد الاستبانات المسترجعة 78 استبانة، تم تحليلها إحصائيا بالأساليب المناسبة المتوافرة ضمن برنامج SPSS. كثفت نتائج التحليل عن وجود علاقة إيجابية وقوية ودالة إحصائيا بين كل من ممارسات الموارد البشرية من جهة، و الرضا الوظيفي للموظفين في المؤسسة العامة محل البحث من جهة أخرى. وقد كانت العلاقة أقوى بين ممارسات التدريب والتطوير و الرضا الوظيفي للموظفين أقوى من العلاقة بين ممارسات تقييم الأداء الوظيفي والرضا الوظيفي للموظفين. ومن هنا، ولتحسين مستويات الرضا الوظيفي للموظفين لا بد من تطوير ممارسات الموارد البشرية، مع الاهتمام بتدريب وتطوير الموظفين، ووضع نظام عادل وفعال للتقييم.

الكلمات المفتاحية: ممارسات الموارد البشرية، التدريب و التطوير، تقييم الأداء الوظيفي، الرضا الوظيفي للموظفين. المؤسسة العامة. 


\section{Introduction}

Organizations seek to record success, keep growing, face competition, and achieve their short and long run objectives. Therefore, organizations develop strategies and set plans in order to be successful in the dynamic and turbulent environment (Javed et al, 2018). Day after day, organizations recognize the fact that their success depends mainly on their valuable assets, human resource (HR). This is because HR is the key of success in the short and long run. The success or failure of an organization is largely dependent on the caliber of the people working therein. Without positive and creative contributions from people, organizations cannot progress and prosper (Armstrong, 2015). This justifies the investments the organizations make in their HR. This also justifies why organizations make continuous efforts to develop their HRM practices (Shaukat, 2018). It is believed that effective HRM practices lead to better performance, and influence both individual and organizational performance (Denisi \& Griffin, 2019). Therefore, hundreds of studies have been taking pace to investigate the relationship between HRM practices and employee behaviours and organizational performance, including employee job satisfaction(Katou, 2017).

As organizations seek to develop their HRM practices, they seek to enhance the job satisfaction of their employees. This is because it is believed that satisfied employees are happier, better performance, and more loyal (Robbins, 2019). It was found that employee job satisfaction influences employee commitment, turnover, absenteeism, tardiness, accidents, and grievances. This is because satisfied employees are more committed, and with low degrees of turnover, absenteeism, tardiness, accidents, and grievances (Moorhead \& Griffinm 2019). By this way, organizations are keen to explore and identify the drivers of employee job satisfaction.

\section{Problem Statement}

Recognizing the importance of HRM practices, and their effects on employee behaviors and attitudes, many studies investigated the correlation between HRM 
practices and employee job satisfaction. This is because it is believed that it is essential to enhance employee job satisfaction to improve their contributions to organizational performance. Besides, it is believed that effective HRM practices influence employee behaviors and attitudes, including their job satisfaction (Byars \& Rue, 2017).

Public corporations in Qatar seek to develop their performance to be able to meet the objectives of the national vision 2030. To meet their strategic objectives, and build their sustainable performance, public corporations in Qatar invest heavily in HRM. At the same time, top management of public corporations in Qatar is keen to develop HRM practices, and find ways to foster employee job satisfaction. Therefore, there is a need to investigate the effects of HRM practices on employee job satisfaction. In the light of that, the current research seeks to investigate impact of HRM practices on employee satisfaction in case of a public corporation in Qatar. This research seeks to answer the following research questions:

1. What is the level of employee job satisfaction at the selected Qatari corporation?

2. How employees at the selected Qatari corporation perceive HRM practices?

3. What is the relationship between HRM practices and employee job satisfaction?

\section{Research Objectives}

The overall objective of this research is to investigate the impact of HRM practices on employee satisfaction in case of a public corporation in Qatar. By investigating such relationship between HRM practices and employee satisfaction, recommendations could be provided for the management of the selected Qatari corporation to foster HRM practices to enhance employee job satisfaction. This in return could help to enhance employee job satisfaction, and this in return may positively influence individual and organizational performance. 
Specifically, the current research seeks investigate the relationship between HRM practices (training and development and performance management) and employee job satisfaction, and identify whether it is positive or negative relationship, and strong or weak relationship.

\section{Importance of the Research}

There are many reasons stand behind carrying this research. The current research seeks to investigate employee perceptions of HRM practices, and their level of job satisfaction. This will be an opportunity for the management of the selected Qatari public corporation to improve HRM practices and enhance level of employee job satisfaction. The current research will help to identify gaps in HRM practices, and issuers of satisfaction or dissatisfaction among employees. At the same time, although HRM practices and employee satisfaction issues have been investigated in different contexts, still, the issues have been rarely investigated in case of Qatar. Besides, although the relationship between HRM practices and employee satisfaction has been investigated in different sectors and industries, but has been rarely investigated in case of public corporations. This means that there is a research gap in this area, especially on public corporations. No study to best of the author knowledge has empirically examined, though, HRM practices and employee satisfaction in public corporations in Qatar. Thus, the current research attempts to fill this gap by investigating the relationships between selected HRM practices and employee satisfaction in a public corporation in Qatar.

\section{Research Hypothesis}

The research seeks to test the following hypothesis:

H1: There is significant relationship between HRM practices and employee job satisfaction. 
$\mathrm{H} 2$ : There is significant relationship between training and development and employee job satisfaction.

H3: There is significant relationship between performance management and employee job satisfaction.

\section{Scope of the Research}

The following points clarify the scope of the research:

1. The current research explores the impact of HRM practices on employee job satisfaction in case of only one Qatari public corporation. Based on that, the study explores the issue of HRM practices and job satisfaction in the case of a single organization, no other organizations was included.

2. Data was collected on February 2021. The results of the study are based on the results of data collected from a relatively small random sample of employees and did not include all employees who work for the selected corporation.

3. The study explored the effects of some HRM practices (training and development, and performance management) on employee job satisfaction, and did not include all HRM practices, or factors that might affect employee job satisfaction.

\section{Literature Review}

\section{The Meaning of Employee Job Satisfaction}

It may seem that it is easy to define employee job satisfaction, but that it is not. This is mainly because there is no one agreed on definition for employee job satisfaction. For example, Davis \& Nestrom (2015) defined employee job satisfaction as a combination of positive or negative feelings that employees have towards their work. By this way, satisfaction is about feelings towards work. 
Such feelings could be positive, so employees tend to be satisfied, or negative, so employees tend to be dissatisfied. For Kaliski (2010), job satisfaction is an employees' sense of achievement and success on the job. This definition focused on the employee senses of success, so satisfaction takes place in case of success, otherwise, employee trends to be dissatisfied. Statt (2014) focused on the relationship between rewards and intrinsic motivation. He argued that job satisfaction is the extent to which an employee is content with the rewards he or she gets out of his or her job, particularly in terms of intrinsic motivation. Armstrong (2015) and George \& Jones (2018) defined employee job satisfaction as a matter of attitudes and feelings. For them, job satisfaction refers to the attitude and feelings people have about their work. Such feelings could be positive (job satisfaction) or negative (job dissatisfaction). Mullins (2015) argued that employee job satisfaction is a complex and multifaceted concept that can mean different things to different people. Job satisfaction is more of an attitude, an internal state. It could be, for example, associated with a personal feeling of achievement, either quantitative or qualitative.

\section{The Meaning of HRM}

It was found that HRM is perceived in different ways and from different perspectives. Some definitions focused on the activities and functions of HRM (Lado \& Wilson, 2014, Buchanan \& Huczynski, 2014). For example, Lado \& Wilson (2004, p.32) defined HRM as "a set of distinct but interrelated activities, functions, and processes that are directed at attracting, developing, and maintaining (or disposing of) a firm's human resources". This approach to define HRM focuses on listing the key functions of HRM. Far away from this approach, modern approaches focus on the strategic role of HRM. For Armstrong (2015, p. 14), HRM is "a strategic and coherent approach to the management of an organization's most valued assets - the people working there whom individually and collectively contributes to the achievement of the objectives". HRM involves all management decision and practices that directly affects the people, or human resources, who work for the organization. 
This brief definition presents the key themes of HRM. On one hand, it shows that HRM role is strategic rather than operational one. In other words, organizations can utilize HRM to serve their strategies and create alignment between their strategies and HRM practices. Other attempts to define HRM try to balance between the HRM functions and the strategic role of HRM. Delaney \& Huselid (2016) define HRM as a comprehensive approach to managing people, and argue that HRM has two objectives: the motivation and development of the employees and the performance and productivity of the organization. This means that HRM underpins the human side of the management and enterprises and employees' relations with their organizations (Osibanjo et al., 2012). It also means that HRM focuses on creating the balance between the interests of both: the organization and the people. Based on that, all HRM policies should be directed to enhance individual and organizational performance. By this way, HRM does not create competitive advantage unless it is managed effectively. The HR must exhibit high levels of skill and the willingness, motivation, and commitment to exhibit productive behavior that are generated by the human resource practices (Wright et al., 2014). For Beardwell \& Claydon (2017), HRM includes both soft and hard variants. While Soft variants focus on the functions of HRM, such as training, development, commitment and participation, hard HRM concentrates mostly on strategy where human resources are used to achieve organizational goals.

\section{HRM Practices and Employee Job Satisfaction}

Recognizing the importance and the significance role of HRM practices, many studies investigated the association between HRM practices and employee job satisfaction. Such studies came up with different conclusions. Overall most studies assure that there is positive correlation between HRM practices and employee job satisfaction. It is argued that there are many drivers of employee job satisfaction, but HRM practices are a key driver of satisfaction (KOÇ, 2014). 
This is because as employees feel that they have opportunities for training and development, and as they find that they are rewarded for their efforts, this positively influences their satisfaction. Besides, as employees feel that their performance is appraised fairly, and their supervisors ken about their career development, they tend to be satisfied (Schmidt, 2017).

In this regard, many studies investigated the relationship between HRM practices and employee job satisfaction in different sectors and industries. For example, Osibanjo et al., (2019) examined the effect of HRM practices on employees' job satisfaction in the Nigerian banking industry. It was that all practices of HRM related to employee job satisfaction. Therefore, they suggested that for organization to develop, it must invest more in the human capital. KOÇ (2014) explored the role of HRM practices, job satisfaction and organizational commitment intentions of employees working in Turkish private organizations. It was concluded that there was a positive relationship between HRM practices (recruitment and selection, training and development, compensation and benefits, performance appraisals) and job satisfaction and organizational commitment. Petrescu \& Simmons (2018) investigated how HRM practices influence workers' job satisfaction. It was found that although HRM practices can raise workers' job satisfaction, if workplace pay inequality widens therefore then non-union members might experience reduced job satisfaction. This means that employee job satisfaction is influenced by many factors, and HRM practices are among but not the only factors. There are other factors influence employee job satisfactions. Jeet (2017) carried a comparative study in India, concluded that employees were more satisfied with training, teamwork and employee participation, and satisfied to small extent with performance appraisal and compensations. The study also revealed that there is no significant difference between the government and private educational institution's faculty scores on all HRM practices. Schmidt (2017) investigated the relationship between training and development on one hand and job satisfaction on the other hand. 
It was found that there was significant relationship between job training satisfaction and overall job satisfaction. Su (2016) investigated the relationship between training and job satisfaction. The study reinforced the significance of job training in HRM practices. The employees' satisfaction with job training that would lead to higher job satisfaction and lower intention to leave was emphasized. Kampkötter (2016) carried a study in Germany and concluded that if tangible benefits cannot be provided or are not tied to the assessment procedure, the use of appraisals with no monetary consequences can be detrimental for open-minded and self-determined employees, as appraisals could then potentially raise expectations that are not fulfilled. Therefore, only effective performance management practices enhance job satisfaction. In simple words, the relationship between performance management and employee job satisfaction does not take place regardless the practices of performance management. Poon (2014) found that when employees perceived performance ratings to be manipulated because of raters' personal bias and intent to punish subordinates they expressed reduced job satisfaction that, in turn, led to greater intentions to quit their jobs.

\section{Conclusion}

Review of the literature related to the relationship between HRM practices and employee job satisfaction revealed that most previous studies took place in different cultures and organizations, but very limited studies took place in Qatar. Side by side, most studies investigated the relationship between HRM practices and employee job satisfaction in private sector, but such relationship was rarely investigated in public corporations.

\section{Research Methodology}

\section{Method}

The current research utilized the survey research method. This method is very popular in managerial studies and has been widely used in studies exploring the relationship 
between HRM practices and employee job satisfaction. It was also decided to use an online survey, because it is easy to collect data within a short time and to do so at low cost. An online survey is cheaper than face-to-face, more accurate, quicker to analyse, easier to use for participants, easier to use for researchers, more honest, more selective, and more flexible (Gonsalez, 2012).

\section{Research Tool}

To develop a survey with high degree of validity and reliability, and make sure that the questions in the survey help to answer the research questions and test the research hypothesis, intensive review was made for the literature related to the relationship and impact of HRM practices on employee job satisfaction. For the HRM practices, the survey questionnaire developed by Petrescu \& Simmons (2018) was used as it is with high degree of reliability and validity. Besides, it includes comprehensive and clear questions. For job satisfaction, the survey included statements related to factors of employee job satisfactions, mainly: pay, supervision, work relationships, promotion, and nature of the work. The survey questionnaire developed by Osibanjo et al., (2018) was used as it is with high degree of reliability and validity. Besides, it includes comprehensive and clear questions.

A 5-point scale is used as follows: $5=$ strongly agree, $4=$ agree, $3=$ somewhat agree, 2 = disagree, and 1 = strongly disagree. Different actions were taken to ensure reliability and validity of the survey. A pilot study of 20 respondents was carried to test the usability and simplicity of the survey. SPSS was used to measure the survey reliability, using the Cronbach's alpha technique. The Cronbach's alpha value was (0.91).

\section{Research Sample}

Simple random sample was selected, because this type of probability sampling is easy to use and has a high degree of objectivity. According to the official statistics, there are more than 2000 employees working at the selected public corporation. 
A computerized online system (Creative Research Systems) was utilized to identify the size of the sample. The size was 92 employees at a confidence level of $95 \%$. After four weeks, the total number of the returned surveys was (78) surveys. This means that the response rate was $(84 \%)$. The survey questionnaire included four questions related to age, gender, educational qualifications, and work experience. For age, analysis showed that the average age of all respondents was 37 years, indicating they represent youth. For gender, the analysis showed that $62 \%$ of the respondents were female, while $38 \%$ were male. For qualifications, the analysis showed that $55 \%$ held a bachelor's degree, and 36\% had a master's or doctoral degree. Finally, for work experience, the analysis indicates that respondents had different levels of work experience.

Table 1: Characteristics of the sample

\begin{tabular}{|l|l|l|}
\hline \multicolumn{1}{|c|}{ Question } & \multicolumn{1}{|c|}{ Answers } & \multicolumn{1}{c|}{ Percentage } \\
\hline \multirow{5}{*}{ Age } & $20-29$ years & $22 \%$ \\
\cline { 2 - 3 } & $30-39$ years & $41 \%$ \\
\cline { 2 - 3 } & $40-49$ years & $23 \%$ \\
\cline { 2 - 3 } & $50-$ plus years & $13 \%$ \\
\hline Gender & Male & $38 \%$ \\
\cline { 2 - 3 } & Female & $62 \%$ \\
\hline \multirow{5}{*}{ Work experience } & High school & $3 \%$ \\
\cline { 2 - 3 } & Diploma & $5 \%$ \\
\cline { 2 - 3 } & Bachelor's degree & $55 \%$ \\
\cline { 2 - 3 } & Master's or Doctoral degree & $36 \%$ \\
\hline & Less than 2 years & $4 \%$ \\
\cline { 2 - 3 } & 2-5 years & $39 \%$ \\
\cline { 2 - 3 } & 5-10 years & $26 \%$ \\
\cline { 2 - 3 } & More than 10 years & \\
\hline
\end{tabular}




\section{Data Analysis and Findings}

\section{Overall Job Satisfaction}

The survey included (20) closed ended questions ask respondents about their satisfaction with pay, supervisors, work relationships, nature of the work, and overall feelings about employment experience. Averages and standard deviations frequencies for questions related to employee job satisfaction were calculated to identify overall level of satisfaction. The table below shows that respondents at the selected Qatari public corporation are satisfied. This is because the overall average of the all (20) statements was 4.02 out of 5.00 , which is close to "agree". This indicates that respondents are satisfied with their job at the selected Qatari public corporation. By this way, respondents have pleasing and positive emotional state and attitudes resulting from their evaluation of their jobs. The table below shows also those respondents who work for the selected Qatari public corporation are satisfied with pay, supervisors, work relationships, nature of the work, and overall feelings about employment experience. The averages of these factors were between 3.95 and 4.15. From the table, respondents were mostly satisfied with work relationships with coworkers, and least satisfied with pay. The highest average was 4.15 for work relationships with coworkers, and the leas average was 3.95 for pay.

Table 2: Overall employee job satisfaction

\begin{tabular}{|l|c|c|}
\hline & $\begin{array}{c}\text { Average (out of } \\
\mathbf{5 . 0 0}\end{array}$ & Standard deviation \\
\hline Satisfaction with pay & 3.95 & 1.00 \\
\hline Satisfaction with work relationships & 4.15 & 0.96 \\
\hline Satisfaction with supervision & 3.97 & 1.00 \\
\hline Satisfaction with nature of work & 4.00 & 1.01 \\
\hline Overall feelings about employment & 4.06 & \\
\hline experience & & \\
\hline
\end{tabular}




\begin{tabular}{|c|c|c|}
\hline Overall job satisfaction & 4.02 & 0.99 \\
\hline
\end{tabular}

\section{HRM Practices}

The current study selected two HRM practices, namely training and development and performance management. The table below shows that respondents perceived HRM practices positively. On one hand, they perceive training and development practices in positive manner. They believe that their organization not only has provided them with training opportunities enabling them to extend their range of skills and abilities, but also their organizations is committed to the training of its employees. At the same time, respondents agree that their organization encourages them to extend their abilities, and pays for any work-related training they want to undertake. Respondents also agree that they get the opportunity to discuss their training requirements with their supervisors. It is noted that the overall average of training and development practices was 4.01; this indicates positive perceptions of such practices. On the other hand, respondents perceived performance management practices in relatively positive manner. They believe that performance appraisal in their organization is relatively fair, as the average of this statement was 3.65 out of 5.00. At the same time, respondents agree that they are allowed to formally communicate with supervisors regarding the appraisal results. Besides, they somewhat agree that their supervisors provides them with conductive feedback about their performance.

Table 3: Employee perceptions of HRM practices

\begin{tabular}{|c|c|c|}
\hline & $\begin{array}{c}\text { Average (out of } \\
\mathbf{5 . 0 0}\end{array}$ & $\begin{array}{c}\text { Standard } \\
\text { deviation }\end{array}$ \\
\hline Training and development & 4.01 & 1.00 \\
\hline Performance management & 3.65 & 0.96 \\
\hline Overall HRM practices & $\mathbf{3 . 8 3}$ & $\mathbf{1 . 0 0}$ \\
\hline
\end{tabular}




\section{HRM Practices on Employee Job Satisfaction}

In order to investing the relationship between HRM practices and employee job satisfaction, Pearson Correlation was calculated between the two variables. Results of data analysis showed that there is positive and strong correlation between HRM practices and employee job satisfaction. The value of Pearson Correlation was significant at 0.000 , which indicates strong relationship. At the same time, it was noted that there was strong and positive relationship between training and development practices and employee job satisfaction. Side by side, there was strong and positive relationship between performance management practices and employee job satisfaction. It was found that although there is was strong and positive relationship between the practices of both training and development and performance management, and employee job satisfaction, still, the value of Pearson Correlation was higher in case of training and development.

Table 4: Correlation between HRM practices and employee job satisfaction

\begin{tabular}{|c|c|c|}
\hline Variables & Pearson Correlation & Significant \\
\hline Training and development practices & 0.533 & $0.000^{*}$ \\
\hline Performance management practices & 0.424 & $0.000 *$ \\
\hline HRM practices & 0.478 & $0.000 *$ \\
\hline
\end{tabular}

In order to identify the impact of HRM practices on employee job satisfaction, a multiple regression analysis was performed. It was found that the value of $\mathrm{R} 2$ was 0.226 , this means that HRM practices explained $22 \%$ of employee job satisfaction. In other words, there are many factors influence employee job satisfaction. HRM practices explain $22 \%$ of employee job satisfaction, while other factors explain $78 \%$. By this way, HRM practices are just one factor influence job satisfaction, there are many other factors. 
Table 5: The impact of HRM practices on employee job satisfaction

\begin{tabular}{|l|c|c|c|}
\hline \multicolumn{1}{|c|}{ Predictor } & t & R 2 & Adjusted R 2 \\
\hline HRM practices & $6.765^{* *}$ & .226 & .218 \\
\hline
\end{tabular}

\section{Discussion of the Findings}

This study revealed that there is strong and positive relationship between HRM practices and employee job satisfaction. By this way, the study main conclusion is similar to conclusions of the studies in the literature. There is similarity between the results of this study and the findings of Osibanjo et al., (2012), Koc (2014), and Jeet (2017), which concluded that HRM related to employee job satisfaction. This assures that HRM practices drive employee job satisfaction. This study found that both training and development, and performance management practices, are related to employee job satisfaction. By this way, the study finding is similar to conclusions of the studies in the literature. There is similarity between the results of this study and the findings of Schmidt (2017) and Su (2016) who found that there was significant relationship between training and overall job satisfaction. At the same time, there is similarity between the results of this study and the findings of Kampkötter (2016) and Poon (2004) who found that performance appraisal relates to employee job satisfaction. This assures that HRM practices are essential to employee job satisfaction. Still, this also means that improving HRM practices is not enough alone to enhance employee job satisfaction. Employees look for effective HRM practices, and get happy with such practices. Still, employees also look for good pay, friendly relationship, attractive organizational climate, effective supervision style, and autonomy. This supports the arguments of Mullins (2005), Kaliski (2000), and Kalleberg (2017) who argue that there is no only one factor contributed to employee job satisfaction, but there are many. 
The current study found that there is significant relationship between training and development and employee job satisfaction. This supports the results of the studies of Schmidt (2017) and Su (2016) who found that there was significant relationship between job training satisfaction and overall job satisfaction. By this way, organizations need to foster their training and development practices, and need to invest in HRD. In order to enhance satisfaction, organizations need to provide training opportunities, and need to take care of training needs, design, methodologies, and content. The current study also found that there is significant relationship between performance management and employee job satisfaction. This supports the results of the studies of Kampkötter (2016) and Poon (2004) who found that performance appraisal relates to employee job satisfaction. Therefore, organizations should carry effective and fair performance management practices. On one hand, to be related to satisfaction, employees look for effective performance management practices. On the other hand, the performance management practices should be fair enough to enhance satisfaction.

\section{Recommendations}

One of the key recommendations is to regularly improve and foster HRM practices to enhance employee job satisfaction. It is also recommended to regularly investigate employee perceptions of HRM practices, and develop such practices in the light of employee perceptions. It is important to clearly and precisely analyze employee training needs to make sure that employees participate in the right training courses at the right time. Side by side, it is important to make training and development opportunities available for all employees the entire tie based on their training needs. Organizations should invest heavily in training and development. Still, to maximize training-performance relationship, it is crucial to design and plan training effectively, and make continuous evaluation for training. Organizations should also improve their performance management practices. 
This requires getting rid of old practices of performance management, and adopting goal-oriented performance management. It is also important to make sure that performance management is based on clear standards, and provide continuous and constructive feedback. Results of performance management should be fair enough and linked to employee real performance. It is important to utilize results of performance management to reward and develop employee performance.

Regarding the future studies, the study found that HRM practices explain $22 \%$ of employee job satisfaction, while other factors explain $78 \%$. There is a need to investigate the other factors that may drive employee job satisfaction, such as leadership style, organizational climate, organizational culture, and support from supervisors and co-workers. As the current study investigated the relationship between only two HRM practices (training and development and performance management), it is recommended to carry future studies about the impact of other HRM practices, such as rewards, selection, and work relationships.

\section{Conclusion}

The main conclusion of the current study is confirming the positive and strong correlation between HRM practices and employee job satisfaction. This means that HRM practices is one of the key drivers of employee job satisfaction. Still, practices explain $22 \%$ of employee job satisfaction, while other factors explain $78 \%$. By this way, there are many factors drive employee job satisfaction, and HRM is a key but not the only one factor. The study also assures the more the employees perceive HRM practices, the more they be satisfied. This justified why the relationship between training and development and employee job satisfaction was stronger than the relationship between performance management and employee job satisfaction. This means that in order to enhance employee job satisfaction, organizations need to foster and develop HRM practices. 


\section{References}

Armstrong, M. (2015). Handbook of Human Resource Management Practice. New Delhi: Kogan Page India.

Buchanan, D. and Huczynski, A. (2014) Organizational Behaviours: An Introductory Text. 5th ed. Harlow: Prentice Hall.

Byras, L. \& Rue, L. (2017). Human resource management. USA: Irwin/McGrawHill.

Davis, K. and Nestrom, J. (2015). Human Behavior at work: Organizational Behavior, 7 edition, McGraw Hill, New York.

Delaney, J. \& Huselid, M. (2016). The impact of human resource management practices on perceptions of organizational performance. Academy of Management Journal, 39(4), 949-969.

Denisi, A. \& Griffin, R. (2019). Human Resource Management. USA: Houghton Mifflin Co.

George, J., \& Jones, G. (2018). Understanding and managing organizational behavior. (5th ed.). Upper Saddle River, New Jersey : Pearson Prentice Hall.

Gonsalez, J. (2012). Present Day Use of the Internet for Survey Based Research. Journal of Technology in Human Services. 19: 19-31.

Javed, M., Ahned, M., \& Khan, M (2018). Impact of HR practices on employee job satisfaction in public sector organizations of Pakistan. Interdisciplinary Journal of Contemporary Research in Business, 4(1): 348-363.

Jeet, J. (2017). Impact of Prevailing HRM Practices on Job Satisfaction: A Comparative Study of Public and Private Higher Educational Institutions in India. International Journal of Business and Management. 4: 89-111. 
Kalleberg, A. (2017).Work values and Job rewards: A Theory of Job Satisfaction. American Sociological Review, 42(1), 124-143.

Kaliski, B. (2017). Encyclopedia of Business and Finance. Second edition, Thompson Gale, Detroit.

Kampkötter, P. (2017). Performance appraisals and job satisfaction. The International Journal of Human Resource Management . 28 (5): 231-249.

Katou, A. (2018). Measuring the Impact of HRM on organizational performance. Journal of Industrial Engineering and Management, 2: 119-142

KOÇ, C. (2014). Human Resource Management Practices, Job Satisfaction and Organizational Commitment. International Journal of Academic Research in Business and Social Sciences. 4 (9): 341-355.

Lado, A. \& Wilson, M. (2014). Human Resource Systems and Sustained Competitive Advantage: A Competency-Based Perspective. The Academy of Management Review. 19 (4): 233-251.

Moorhead, G. \& Griffin, R. (2019).Organizational behavior - Managing people and organizations. Delhi: AITBS Publishers \& Distributors.

Mullins, J. (2015). Management and organizational behavior, Seventh Edition, Pearson Education Limited, Essex.

Osibanjo, P. Kehinde, A. Abiodun. A. (2019). Human Resource Management and Employee Job Satisfaction: Evidence from the Nigerian Banking Industry. Journal of Economics and Business Research, 1: 17-32.

Petrescu, R. \& Rob, S. (2018). Human resource management practices and workers' job satisfaction. International Journal of Manpower, 29 (7): 651-66 
Poon, R. (2014). Effects of performance appraisal politics on job satisfaction and turnover intention. Personnel Review, 33 (3): 322-334.

Robbins, S. (2019) Organizational Behavior. Prentice-Hall of India

Shaukat, H. (2015). Impact of Human Resource Management Practices on Employees Performance. Middle-East Journal of Scientific Research . 23 (2): 329-338.

Schmidt, S. (2017). The relationship between satisfaction with workplace training and overall job satisfaction. Human Resource Development Quarterly. 18 (4): 481-498

Statt, D. (2014). The Routledge Dictionary of Business Management, Third edition, Routledge Publishing, Detroit.

Steijn, B. (2014). Human Resource Management and Job Satisfaction in the Dutch Public Sector. Review of Public Personnel Administration. 23 : 245-261

$\mathrm{Su}, \mathrm{R}$. (2016). The mediating role of job satisfaction in the relationship between job training satisfaction and turnover intentions. Industrial and Commercial Training, 48 (1): $42-55$.

Wright, P. McMahan, G. \& McWilliams, A. (2014). Human Resources and Sustained Competitive Advantage: A Resource-Based Perspective. International Journal of Human Resource Management, 5 : 301-326.

Copyright (C) 2021 Dr. Thamer Mohammed Maharmeh, AJRSP. This is an open-access article distributed under the terms of the Creative Commons Attribution License (CC BY NC).

Doi: doi.org/10.52132/Ajrsp.e.2021.263 